\title{
MEDICARE I97I: CHANGING ATTITUDES AND CHANGING LEGISLATION
}

\author{
IRWIN WOLKSTEIN*
}

The 1971 Congressional session began with the proposed social security amendments, containing important changes in the Medicare legislation, being assigned House of Representatives bill number H.R..$^{1}$ This symbolic number indicated that this bill, introduced jointly by Chairman Mills of the Committee on Ways and Means and Congressman John Byrnes, the senior minority party member of the committee, would receive first priority attention by the committee and the Congress. This high priority and the bill itself can be traced to the previous Congress, where social security amendments had been passed by both the House and the Senate in 1970, but failed of enactment. The amendments, which had passed the House of Representatives on May 27, also passed the Senate on December $29 .{ }^{2}$ Although the Senate appointed conference committee members, the House did not, the leadership of the House taking the position that there was insufficient time in the few days left in the post-election, lame-duck session to settle House-Senate differences with respect to the bill. The fact that the 1970 amendments had included an increase in cash payments to social security beneficiaries, and the desire to enact such an increase and pay it as early in I97 I as possible, accounted for the urgency of early action on social security in the new Congress.

In addition to the proposed changes in Medicare and the social security benefit increase, H.R. I contained measures to modify social security cash benefits in a number of other ways, to change Medicaid substantially, and to drastically revise the welfare program of the nation. It soon proved impossible to achieve early enactment of all the provisions of this complicated and important measure. As a result, by agreement of the important members of both houses, the cash social security benefit increase was acted on separately, ${ }^{3}$ with the remainder of the bill left for more extended consideration. Then, because H.R. I was essentially the same as the bill approved by the House of Representatives in 1970 and the matters up for consideration had been thrashed out at length in I970, some short-cuts to action on the remainder of the bill seemed reasonable. Accordingly, the House committee dispensed with open hearings on H.R. x. During the executive sessions, however, new points of view-especially on welfare reform-developed, and the committee's deliberations were protracted. The bill was not ordered reported out until May 26.

While we cannot be certain at any point before the legislative action is com-

* Deputy Director, Bureau of Health Insurance, Social Security Administration.

1 H.R. r, 92d Cong., rst Sess. (r97r).

${ }^{2}$ H.R. I7550, 9rst Cong., 2d Sess. (I970); II6 Cong. REc. S21,346 (daily ed. Dec. 29, I970).

${ }^{B}$ Pub. L. 92-5, title II (Mar. I7, I97I). 
pleted just what will be the outcome, we already know a good deal about what is likely to occur and its background, since the legislative history of H.R. I consists largely of the record of the 1970 social security amendments. But for the purpose of this paper, which is to understand the significance for the Medicare program of the pending legislation, it is necessary to go even further back in time.

\section{I}

\section{The Originat Medicare Legislation}

The changes in Medicare that are proposed to be made by the Social Security Amendments of $197 \mathrm{r}$ may leave an important mark in medical care history. These amendments may represent the point at which a significant change occurred in the approach taken by the federal government in the Medicare program to the health services industry, a change from a position of neutrality to a position of active intervention.

In reporting out the Medicare bill in 1965 , the Committee on Ways and Means of the House of Representatives pointed out, "The bill specifically prohibits the Federal Government from exercising supervision or control over the practice of medicine, the manner in which medical services are provided, and the administration or operation of medical facilities." which it refers expressed the idea that Medicare as enacted was intended to be largely a neutral factor in health care. Specific provisions of the law, such as those requiring utilization review by hospitals and nursing homes, were innovative and more far-reaching in dealing with health care than were the then-existing private insurance or welfare health programs, but Medicare law generally followed the precedents of the better private insurance plans in its benefits, its approach to paying claims, and its method of determining the amount of reimbursement. Medicare's quality protection provisions relied heavily upon the standards of the Joint Commission on Accreditation of Hospitals. Its administration was delegated in large part to private insurance companies and state agencies.

Medicare originally followed the tried, even if not necessarily always true, paths to coverage of health services. Following the precedents is not surprising in a political matter. President Johnson, in whose term Medicare was enacted, was famed during his tenure in the Senate and his early years in the Presidency for his ability to form consensuses and his consequent success in obtaining enactment of his legislative program. Wilbur Mills, chairman of the Committee on Ways and Means of the House of Representatives and the most significant figure in Congress with respect to social security and Medicare, has also met very few defeats with the legislation he has supported; he, too, is a consensus maker. One of the ways to improve the prospect that proposed legislation will be acceptable is to build into its design concepts that have already obtained acceptance among the parties at interest.

\footnotetext{
'H.R. REp. No. 89-213, 89th Cong., Ist Sess. 2x-22 (1965).
} 
Another way to gain a consensus of approval is to balance provisions that one of the parties opposes with others that the same party favors. This second step also seems to have been important to the initial design of Medicare, which combines, for example, social security compulsory contributions for hospital insurance with voluntary coverage of physicians' services based on currently paid premiums. Some favored one and some the other provision, and some favored the third element of the law, an expanded medical assistance plan. There was appeal also to different groups in the approaches taken in the law to the benefits that were providedMedicare hospital benefits being patterned largely on the Blue Cross model and Medicare physicians' coverage being largely patterned on the major medical insurance model.

Some might think that all the delicate maneuvering in the design of the bill and all the concessions made to the insurance and health establishment were unnecessary from a political point of view in 1965 since at that time the House of Representatives, following the Democratic landslide victory in the election in 1964 , was composed of the highest proportion of liberal legislators in many years. Yet the key vote on Medicare in the House in 1965 carried by a margin of just fortyfive votes. A switch of twenty-three votes would have meant recommittal of the bill to the committee and the almost certain death of the proposal in that Congress. The opposition to the bill was based in significant part on concern about the degree of federal invasion into medical care that would result. It is not surprising that there were few, if any, voices raised in either the House floor debate or in the Senate consideration of the bill to strengthen its control over medical care in any substantial way. From all indications, many, if not a majority, of the policy makers of the country in the mid-rg6os would probably have opposed strengthening the federal government's hand further than did the initial Medicare legislation to permit more direct intervention by the government in health affairs.

\section{II}

\section{The Intervening Years}

\section{A. Changing Attitudes}

In the six years since the enactment of the Medicare program, there has been a tremendous change in the country, and not the least significant aspect of this change has been one of attitude. It is not clear whether the change is transitory or permanent but its effects may be significant and long-lasting. The change involves medical care in the United States, but it is much more pervasive. Precedents and authority that were until quite recently accepted almost without question are now being resisted. We can hardly escape being aware of the unrest in regard to race relations, environmental pollution, education, defense, and the draft. There is discomfort with what is felt to be a worsening of all services and the rise in all prices. There is a reduced inclination to accept the word of the Establishment on what 
to do or not to do about these problems, and the attitude that pervades the country has led, for example, to almost unprecedented Congressional questioning of military appropriation requests. Medical care-especially medical services and prices-has become a subject of particular concern. It seems likely that one unrest reinforces another, and the interaction of many forces seems to be at work. One of the results seems to be an increased recognition of the consumer and public interest and some decline in the importance of special industry interests.

The difference between the pre-Medicare days and the present can be illustrated by comparing the words used by Senator Anderson, one of the foremost supporters of Medicare, in defense of his plan with the arguments of current proponents of national health insurance. In Ig62, Senator Anderson said,

Under the [Medicare] amendment the Government would assume no responsibility for providing medical services, but would only help older people finance the costs of their most burdensome health expenses through a program of basic health insurance. Aside from the difference in the method of collecting contributions and the fact that the proposed insurance is only for the elderly, what is proposed is very much like what Blue Cross has been doing for years-paying hospital bills without meddling in hospital operations. ${ }^{5}$

By way of contrast, Senator Edward Kennedy, a major sponsor of national health insurance, supported his plan by saying,

The organization and delivery of health care is so obviously inadequate to meet our current health crisis that only the catalyst of national health insurance will be able to produce the sort of basic revolution that is needed if we are to escape the twin evils of a national health disaster or the Federalization of health care in the seventies. ${ }^{6}$

Before $I_{965}$ the adoption of Medicare was considered more acceptable if it would not change things, and now national health insurance is considered in important quarters to gain support if it will change things drastically.

Other examples of the growth in prevalence of the attitude that government in general and Medicare in particular should actively intervene in medical care include a report by the Medicare permanent consultant group, the Health Insurance Benefits Advisory Council, more than half of whose members are physicians. The Council recommended, among other things: (I) legislation to provide authority to expel from the program physicians or other providers of health services who abuse the program or provide grossly inferior services, (2) development of quality standards to be applied to physicians' services, (3) program authority to apply hospital health standards that go beyond those of the Joint Commission on Accreditation of Hospitals, and (4) legislation to assure that reimbursement under Medicare would not be inconsistent with the plans and findings of health facility planning bodies.?

\footnotetext{
s 108 CONG. Rec. 13,645 (1962).

Irs CoNG. Rec. 39,284 (I969).

7 Health Insurance Benefits Advisory Council, Anndar Report on Mebicare (ig69).
} 
All these proposals are for controls that probably were unacceptable to almost all of the health establishment only a few years ago.

This advisory council report was only one of a number of reports finding serious problems to exist in medical care and proposing corrective action. The medical cost problem had come to be considered especially critical. Only eight months after Medicare became effective, President Johnson, reflecting this concern, issued a directive to the Secretary of Health, Education, and Welfare, John W. Gardner, to convene a National Conference on Medical Costs, which was held in June Ig67.8 Numerous reports on various aspects of the health care crisis ensued, including a Ig67 report by the Secretary's Advisory Committee on Hospital Effectiveness; a I967 report of the National Advisory Commission on Health Facilities; a I967 report, Promoting the Group Practice of Medicine, by the National Conference on Group Practice; and a rg68 report of a conference of the National Academy of Engineering on the Costs of Health Care Facilities. Most reports declared the major problem to be defects in the medical care system. Inevitably the question was brought to government for action. And there was action. Among the steps taken was the enactment of state legislation in New York and Massachusetts establishing authority for those states to set rates for hospital reimbursement. ${ }^{9}$

The only Medicare legislation that has been enacted in response to this hue and cry was a provision of the Social Security Amendments of 1967 which gave the Secretary of Health, Education, and Welfare authority to experiment with devices which depart from Medicare's normally required cost reimbursement of institutions and fee reimbursement of physicians and other noninstitutional suppliers of Medicare services. These departures were allowed if they promised to create additional incentives for increasing the efficiency and economy of health services..$^{10}$

A I970 report of the staff of the Senate Committee on Finance, which included some very sharp criticisms of Medicare's operations as well as of the way medical care is delivered and charged for, played a part in setting the stage for the r970 congressional consideration of changes in Medicare. The staff said, among other things, that

Under present law, the institutional suppliers of covered health services under medicare (and medicaid, in large part, also) are paid whatever it costs them to provide the services. Physician bills under medicare are essentially paid as rendered. Unlike most areas in the private economy no incentives exist to produce or supply a given health service at the most economical price consistent with quality of care. To the contrary, hospitals and extended care facilities can, under present medicare and medicaid reimbursement rules, spend money on virtually anything and be paid for it by Government. ${ }^{11}$

\footnotetext{
${ }^{8} 3$ Weerly Comptlation of Prestoential Documents 349 (I967).

- A. Somers, Hospital Regulation: The Dilemma of Public Polict i66-7o (ig69).

${ }^{10} 42$ U.S.C. $\S \mathrm{r} 395 \mathrm{~b}(\mathrm{I})$ (a) (I968).

11 Staff of Senate Comm. on Finance, 9ist Cong., ist Sess., Medicare and Medicatd: Problems, Issues, and Alternatives I (Comm. Print r970).
} 


\section{B. Development of the Administration's Position-r969-1970}

President Nixon expressed his position on the health system on July Io, I969, when he said,

We face a massive crisis in this area [health care] and unless action is taken, both administratively and legislatively, to meet that crisis within the next 2 to 3 years, we will have a breakdown in our medical care system which could have consequences affecting millions of people throughout this country. ${ }^{12}$

Increasingly Medicare has become a focus of attention of those interested in medical care changes. The program has been placed in this position in part because it is by far the biggest government health services program, paying for about onetenth of all the health costs of the nation, and its very size seems to require it to take responsibility for medical care. Furthermore, people look to government to provide leadership when they seek reform. Finally, the problem of rising costs has important effects on the financing of the Medicare program. Rising costs have required increases in (I) the percentage of payroll assessed to support Medicare's hospital insurance (part A of the Medicare law); (2) the copayment required of patients under part A; and (3) the premiums paid by the aged that, with a matching government contribution, support Medicare's coverage of physicians' services (part B of the Medicare law). Since Medicare is substantially affected by rising costs, it seems reasonable that the program should not sit idly while costs skyrocket. But people expect Medicare to do more than protect itself and its contributors. People look at Medicare as a possible instrument of change affecting all medical services because they consider Medicare reimbursement to have a strong potential as a lever for change of the entire system.

Reform of the health system and control of health costs are goals that are more easily stated than achieved by government action. Three kinds of problems are involved. First, there are no explicit and generally agreed upon goals for the health system of the country. No conclusion has yet been reached on how good our health system should be, how much health expense is acceptable, and how much intrusion by the government into the system is appropriate. Second, there is little basis for knowing in advance the effectiveness of various steps we might take to change the economic and social factors involved in medical care. Third, many steps that seem from one point of view to be advantageous also seem to have possible disadvantages. For example, if the government pays less for services under its programs, reducing the financial burden on contributors to Medicare, access to services of patients covered by the government program may decline, patients may be required to pay more out-of-pocket when they receive services, or providers of services may suffer an excessive reduction in income and their future operations may be curtailed.

All these difficulties and others were taken into account as the 1970 proposals of the administration for Medicare were developed. Some of these proposals were

\footnotetext{
${ }^{12} 5$ Weekiy Compilation of Prestoentiat Doctuments 963 (I969).
} 
made as part of the administration-sponsored "Health Cost Effectiveness Amendments of 1969," submitted when the administration testified before the Committee on Ways and Means in October 1969. ${ }^{13}$ It seems notable that in this case the tightening up that was proposed was not accompanied by sweeteners to appease those affected. The bill was designed for the purpose of doing seven things:

I. tying Medicare and Medicaid payments related to hospital and extended care facility capital costs to state health planning approval of the capital expenditure;

2. making corporate planning by provider institutions a condition of participation in Medicare;

3. expanding authority for Medicare-Medicaid experiments and demonstration projects related to reimbursement methods providing incentives for efficiency and providing authority for testing other program modifications that might lower costs;

4. providing authority to bar from participation in the Medicare and Medicaid programs those providers of services and physicians who abuse them;

5. paying only customary charges of providers of services, normally paid on a reasonable cost basis under Medicare, if such charges were less than this cost;

6. extending the provision for withholding Medicare payments for hospital and extended care where utilization review finds services are not warranted to cases where the stay is not of extended duration (the original law applied such a provision to stays of extended duration); and

7. expanding authority to recover Medicare overpayments.

Robert M. Ball, Commissioner of Social Security, commented on these proposals as follows:

These are important changes, but no one would for a minute suggest that they will reverse the trend of rising medical prices, which is related to long-range factors of supply and demand and to increasing costs in the operation of hospitals. But I do believe that these changes would improve our ability to hold down the increase. ${ }^{14}$

A significant addition to the administration's program was announced at a hearing before the Senate Committee on Finance in February I970 following the issuance of the staff report previously referred to. At that hearing, Under Secretary John G. Veneman described two further administration proposals as follows:

Now, I believe the time has come to make some fundamental changes in the law which governs both medicaid and medicare reimbursement. We have talked a lot about incentive systems and I believe the time has come that we need an incentive system of institutional reimbursement. We also need changes in the

\footnotetext{
${ }^{12}$ Hearings on Social Security and Welfare Proposals Before the House Comm. on Ways and Means, 9Ist Cong., rst Sess., pt. 2, at 556 (I969).

16 Id., pt. I, at 158 .
} 
law that will help control the increases in the amount that the medicare program will recognize in the charges of the individual practitioners.

In the cases of hospitals and other [institutional] providers of services . . . the reimbursement is now based upon reasonable cost which is determined retroactively. This is true not only for Government programs but for the majority of Blue Cross plans. Hospitals consequently do not have a strong economic reason for trying to improve the efficiency of their operation. As their costs are reduced, they receive less money and as their costs rise, as long as they are within the scope of payable charges and are in line, they can be sure of having a large part of them paid by the third-party payers.

I think the time has come that we should move in the direction of determining reimbursement prospectively instead of retroactively. With the rates set in advance the provider would be challenged to stay within the limits of the known reimbursement to be received and the provider would share in savings that come from economies that are achieved through effective management.

Thus, the economic incentives for efficiency and economy in the rendition of services would for the first time be introduced in the program's methods of payment. In this way, we would harness the ingenuity of thousands of managers and policymakers in our health institutions to the objectives not only of quality care but of effective and efficient management. . . .

I do not want to suggest in any way that this would be a simple task and it is going to take a great deal of time to come up with a satisfactory approach for prospective reimbursement. But I believe that the benefits that can be obtained more than merit the efforts to move as rapidly as possible in the direction of an incentive formula based upon prospective rate determination.

We also are suggesting that the law should be changed so as to limit further the rate at which increases in physicians fees would be recognized by medicare. The basic difficulty at the present time is that despite the improvements which have been made in applying reasonable charge guidelines, the best that can be done under the present law is to introduce a lag in the recognition of fee increases. Under the present law the amount the physicians charge is the controlling factor in determining program liability under the supplemental medical insurance program and the reasonable charge is derived from the individual physician's customary charge so long as it does not exceed the prevailing charge in his particular locality and the level of fees recognized under comparable circumstance by the contracting carrier in its own business.

We believe that it is necessary also to move in the direction of an approach to reasonable charge reimbursement that ties recognition of the fee increases to some index. Under such an approach allowable charges recognized for medicare would next year be generally limited to either presently recognized charges or to a new prevailing level set at the $75^{\text {th }}$ percentile of the 1969 average customary charges for a given service in an area. 
In the future the prevailing charge fee would move upward under this plan only in proportion to increases in an index which is made up of pertinent portions of wage and price indices. Under such an approach, recognition of fee increases would continue but only in relation to those things that have a bearing on the physician's cost of doing business. ${ }^{15}$

Another significant proposal was announced in a statement by Secretary Finch in March r970 when he suggested the use of health maintenance contracts to induce the redirection and improvement of the delivery of health services. He said,

We are asking for authority, under the Medicare and Medicaid law, to enter into health maintenance contracts guaranteeing health services for the elderly and the poor at a single fixed annual rate for each person served. ...

In the case of Medicare, the patient will be entitled under such a contract to all of the usual Medicare services plus preventive services. The contract price will be negotiated in advance at an amount less than the Social Security Administration presently pays for conventional Medicare benefits in the locality.

-...

The ultimate goal will be to give every beneficiary of these programs a choice between obtaining services from a health maintenance organization or arranging for them in the usual way from individual doctors and hospitals. . . .

Through such legislation we hope to accelerate the coming of a new era of diversity and competition for health care in the United States, based on informed consumer choices and private incentives that operate within the framework of Government safeguards.

We will not prescribe the form of a health maintenance organization but we will be concerned about the result it produces. . . . ${ }^{16}$

The bill that was passed by the House of Representatives on May 2I, I970, included nine of the ten administration Medicare proposals related to cost or delivery of health care (the exception being an amendment to ease collection of overpayments) although some administration proposals were substantially modified. Two cost control provisions were added during considerations of the Committee on Ways and Means and included in the House-passed bill. (One tightened up on payments made for the services of teaching physicians, and the other improved control on payments to physicians by restricting the persons to whom payment would be permitted.) The posture of the committee, then, was to go at least as far as the administration in tightening up the provisions of Medicare (and Medicaid) vis-à-vis the health services industry.

\footnotetext{
${ }^{28}$ Hearings on Medicare and Medicaid Before Senate Comm. on Finance, 91st Cong., 2d Sess., pt. I, 2t 7-9 (I970).

${ }_{10}$ Robert H. Finch, Secretary of HEW, Statement on Medicare and Medicaid Reforms, HEW News, Mar. 25, I970, at 8-II.
} 


\section{The Administration's Position-1971}

H.R. I was introduced in the House of Representatives on January 22, I97r. Before committee consideration of the bill's Medicare provision began, the administration sent to the Congress a presidential message proposing the development of a "national health strategy" that would assure equal access to care for all Americans and foster improved efficiency in the nation's medical care system. An important part of this strategy was the President's proposal for a "national health insurance partnership," which would include improved private health insurance coverage for working people, by requiring employers to provide their employees with basic health insurance coverage that met federal standards; a Family Health Insurance Plan, financed and administered by the federal government, that would provide basic coverage for welfare families; and improvements in existing federal insurance programs, including Medicare. ${ }^{17}$ With this proposal, the administration joined the growing number of individuals and groups (including the AHA, the AMA, the health insurance industry, the UAW, and the AFL-CIO) who support increased federal intervention in the health care system, and an increased role for comprehensive insurance coverage financed, at least in part, from federal funds.

The President's message also made some specific recommendations with respect to Medicare. These were considered by the committee in executive session. One proposal would eliminate the beneficiary premium under the supplementary medical insurance program (part B of Medicare) and finance the program entirely from social security taxes. Thus, the cost to the aged, and the burden on them from increasing health costs, would be reduced. The message also stressed the need for reorganization of health services and seemed to place main reliance on support for health maintenance organizations to achieve this reorganization. Another measure given support by the message was "preserving cost consciousness." This point seemed to suggest further reliance on patient cost-sharing as an important element in the administration's plans. And, in fact, the testimony of Secretary Richardson before the Committee on Ways and Means in executive session ${ }^{18}$ supported cost-sharing for Medicaid and the proposed new Family Health Insurance Plan for the indigent as well as for increased cost-sharing for Medicare. The cost-sharing was expected to reduce the costs of the programs. The administration's proposals for costsharing changes in Medicare were ( $I$ ) to make the deductible applied to part $B$ of Medicare dynamic by having it increase as physicians' fees rose and to reflect the rise in fees that has occurred since the program became effective, rather than to remain static at fifty dollars as provided in present law; and (2) to apply a coinsurance to each day of hospital care beginning with the tenth day rather than the

\footnotetext{
${ }^{17}$ Message from the President of the United States Relative to Butlding a Natjonal. Health Strategx, H.R. Doc. No. 92-49, 92d Cong., Ist Sess. (Feb. 18, x971).

${ }^{18}$ Statement of Elliot L. Richardson, Secretary of HEW, Before House Comm. on Ways and Means, Feb. 2, 197I.
} 
sixty-first day as in present law..$^{19}$ Secretary Richardson in his statement to the committee also proposed giving an expanded role to the medical profession in peer review activities to help avoid the provision of payment for unneeded health services.

\section{III}

\section{Action by the Ways and Means Committee-rg7i}

The Medicare provisions of the social security bill that was finally reported out by the Committee on Ways and Means on May 26, I97x, can be placed in three categories. First, there was the group of provisions that had passed the House in H.R. I7550. One change in these provisions is worth mentioning: The Senate had modified the provision of H.R. I7550 concerning reimbursement of teaching physicians, under which such physicians would be reimbursed under part $A$ on a costequivalent basis, ${ }^{20}$ and the committee adopted essentially the version as changed by the Senate. An addition to the I970 bill made by the House committee provided for experimentation with peer review in the Secretary's over-all authority to conduct experiments under titles V, XVIII, and XIX. ${ }^{21}$ This addition reflected support for peer review that was part of the administration's national health strategy. ${ }^{22}$

Second, the bill as reported out included, with substantial modifications, the Medicare-related provisions in the administration's health care package. The administration plan for making the part $B$ deductible dynamic was transformed into a one-time increase from fifty to sixty dollars; the proposal for copayment by patients with the tenth day of hospital stay was made effective with the thirty-first day, and its cost reduction effect was offset by entitling beneficiaries to an increase in the number of days covered under Medicare's so-called lifetime reserve provision. The watereddown version of the administration's cost-sharing proposals was adopted after a deliberate release of information on a "tentative decision" by the committee of a stricter version and the subsequent expected public reaction against much stiffer cost-sharing requirements. ${ }^{23}$ However, the administration proposals were accepted in part, thus following the pattern of allowing all parties to claim victory and none to achieve it fully. The rule of compromise prevailed again.

The House also compromised with respect to a provision for peer review sponsored by Senator Wallace F. Bennett and passed as part of the Senate-passed version of H.R. I7550. This provision would have provided for a new system of professional medical review of services by the establishment of Professional Standards Review Organizations. These organizations would represent substantial numbers

\footnotetext{
${ }^{10}$ Letter from Elliot L. Richardson, Secretary of HEW, to Rep. Wilbur D. Mills, Chairman, House Comm. on Ways and Means, Mar. I6, I97r.

${ }^{30}$ H.R. I, 92d Cong., Ist Sess. $\$ 227$ (I97I).

a1 Id. $\$ 222$.

32 Dep't of Health, Education, and Welfare, Towards a Comprehensive Health Policy for the I970's; A WhIte PAPER 52 (197I).

${ }^{23}$ Washington Post, Apr. 3, 1971, at A2, col. I.
} 
of physicians in local areas, would undertake to review utilization of physicians' services, wherever provided, and to judge whether inpatient care is being received at the appropriate type of institution or whether a lower level of care would suffice. The organizations would also have authority to approve in advance Medicare or Medicaid elective hospital admissions. The amendment was described as having "the potential for moderating the costs of health care by as much as 20 percent."24

The third, and probably most far-reaching result of the committee's deliberations on Medicare, was its proposal for the addition of disabled people to those covered by Medicare. This action had not been proposed by the administration and had been rejected by the committee the previous year. The earlier committee report on the bill gives its conclusion concerning this major extension of Medicare:

While your committee believes that extending hospital insurance protection to these beneficiaries would be most desirable, it has regretfully concluded that such an extension is not advisable at the present time.

... The high cost ...., together with the need to bolster financing for the existing hospital insurance program for the aged ...., raised serious problems for which the committee found no immediately acceptable solution. ${ }^{25}$

However, in view of the consensus of support from almost all parties for increased federal financial aid to ease access to care, it should not be surprising that, when the cost no longer seemed an important political issue, the committee acted to cover the group which it had indicated a year earlier, in its opinion, it was most desirable to cover. While providing coverage of the disabled, the committee rejected the administration proposal to drop the part B premium, and merely provided a limit on premiums that would guarantee that the rise in premiums would not outpace the rise in social security benefits. The two actions-the addition to and deletion from the administration's plan-closely balanced each other in terms of their cost effects. As a result of its action on the premium, the committee solved a problem that had previously deterred action to cover the disabled. If the part B premium paid was purely a function of actuarial cost for the entire group covered, aged plus disabled, covering the disabled, with their very high medical costs, would have had the effect of raising the premium charged to the aged while giving them no advantage, a result which was considered unacceptable. The committee action freed the program from the need to set the premium for enrollees at the level of half the actuarial cost of the group covered but provided that the premium be set at a maximum of half the actuarial cost of the aged with the difference between the full actuarial cost for part $B$ coverage and the premiums paid by enrollees coming from general revenues. Thus, general revenues would under the committee's plan in the future pay slightly more than half the cost of part B benefits. Furthermore, the committee's plan, which required the disabled to pay a premium (and the federal government to supplement the premium to the total cost of the part B coverage) and made the disabled eligible

\footnotetext{
${ }^{24}$ Senate Comm. on Finance, 9rst Cong., zd Sess., Press Release, Sept. 30, 1970.

${ }^{25}$ H.R. REP. No. 9I-I096, 9Ist Cong., $2 d$ Sess. 63 (r970).
} 
for Medicare only after twenty-four months of disability, reduced the cost effects on the federal budget to less than would have been the case under, for example, the plan that had been suggested by the Social Security Advisory Council ${ }^{26}$ and apparently resulted in a cost and financing plan acceptable to the committee. The committee's report says,

While your committee has concluded that considerations of public policy dictate the extension of medicare protection to the disabled, your committee also believes, given the cost and financing considerations involved in such coverage, that it is imperative to proceed on a conservative basis. ${ }^{27}$

\section{IV}

\section{Cost Control Provisions}

The more important cost control provisions contained in H.R. I as reported by the committee, as well as in the amendments of last year, merit consideration in some detail.

\section{A. Limitations on Reimbursement Related to Capital Expenditures}

In I967 the Senate added to a House-passed bill a provision that would have withheld reimbursement to providers of services with respect to capital expenditures that were inconsistent with state or local health facility plans. Because of objections of the House members, perhaps reflecting to some degree the objections of the hospitals, this provision was rejected by the conference committee on the bill. ${ }^{28}$ However, a similar provision was included in the Medicare amendments that passed the House in June 1970 . Here the change of mind since 1967 is explicitly expressed.

\section{B. Prospective Reimbursement}

The administration had proposed in I970 that authority be provided for the Secretary of Health, Education, and Welfare to establish prospective rates of payment for institutions that, under present law, were paid on a retrospective cost basis. In 1965 the Committee on Ways and Means explained the reimbursement approach it had adopted in the following words:

Although payment may be made on various bases the objective, whatever method of computation is used, will be to approximate as closely as practicable the actual cost (both direct and indirect) of services rendered to the beneficiaries of the program so that under any method of determining costs, the costs of services of individuals covered by the program will not be borne by individuals not covered, and the costs of services of individuals not covered will not be borne by the program. ${ }^{28}$

\footnotetext{
${ }^{20}$ Report of Advisory Counctl on Soctal Security, H.R. Doc. No. 92-80, 92d Cong., Ist Sess. (I97I).

${ }_{37}$ H.R. REP. No. 92-23I, 92d Cong., Ist Sess. 67 (I97r).

${ }^{28} \mathrm{H} . \mathrm{R}$. REP. No. 90-I030, 90th Cong., Ist Sess. 45-46 ( 1967$)$.

${ }^{20}$ H.R. REP. No. 89-2I3, supta note 4, at 32 .
} 
Prospective rates as proposed by the department would have had elements of both carrot and stick. An added financial reward-above cost-would be paid to institutions that had costs below the established prospective rate, and penalties would be suffered by institutions with costs higher than the established rate. The hope was that announcing the rate before costs are incurred would induce actions to lower the costs of many institutions. The payment rates, rewards, and penalties were to be so set up that both the institutions and the government, as well as patients using their services, would gain as costs were better contained. The administration requested authority to apply such prospective rates but proposed a very flexible basis for proceeding. Reasoning that experience with such an approach was very limited, the administration indicated it might use several different approaches in different places and would institute the process gradually as ways to do so appeared feasible.

The House committee had a number of reservations about the plan for prospective reimbursement and decided in 1970 and again in $197 \mathrm{I}$ to recommend as a regular provision of law only the stick aspects of prospective rates and to leave the carrot as something to be tested by experiments which it authorized. Thus, the administration proposal was translated into two provisions, one authorizing experiments with prospective rates and the second authorizing the Secretary to set prospective upper limits on costs that would be reimbursable but not providing a profit if costs were below this level. The committee explained its rejection of rewards for keeping costs below the prospectively set rate in the following way:

[I]t is not clear that the rates set would result in government reimbursement at levels lower than, or even as low as, that which would result under the present retroactive cost finding approach. Providers could be expected to press for a rate that would cover all the costs, including research costs and bad debts, as well as margins of safety in the prospective rates that might result in reimbursement-if their requests were met-in excess of the costs that would have been reimbursed under the present approach. Moreover, any excess of reimbursement over costs to voluntary providers would probably be used to expand services, and the new level of expenditures might be reflected in setting higher prospective rates for future years.

Also to be considered is the fact that under prospective reimbursement it will be necessary to take steps to assure that providers do not cut back on services necessary to quality care in order to keep actual costs down and thus increase the difference between costs and the prospective rate established. The development of adequate and widely-agreed-upon measures of quality of care will clearly be needed to provide that assurance and should be immediately developed by the Department.

In view of the far-ranging implications of such a change in the approach to reimbursement, your committee's bill provides for a period of experimentation under titles XVIII, XIX and $V$ with various alternative methods and techniques of prospective reimbursement. ${ }^{30}$

\footnotetext{
${ }^{80}$ H.R. REP. No. 92-23 , supra note 27 , at 80-8I.
} 
As indicated above, the committee did adopt a provision for applying prospective upper limits to the costs that would be reimbursable. The committee recognized that even this provision would be difficult to apply well. Its report makes this point as follows:

Your committee recognizes that the initial ceilings imposed will of necessity be imprecise in defining the actual cost of efficiently delivering needed health care. And your committee recognizes that these provisions will apply to a relatively quite small number of institutions. The data that are available for this purpose will often be less than perfectly reliable-for example, it may be necessary to use unaudited cost reports or survey or sampling techniques in estimating the costs necessary to the efficient delivery of care. Under medicare's administrative system, however, cost reports prepared by the providers are now being submitted more promptly after the close of the accounting period and should be available for analysis in the next year and for the establishment of limits in the second following year. Also, the precision of the limits determined from these data will vary with the degree to which excessive costs can be distinguished from the provision of higher quality or intensity of care. ${ }^{31}$

In making the decision to place limits on reimbursable costs, the committee had to make a second decision-who should bear the burden of the nonreimbursable costs that would occur if actual costs exceeded the limit? The committee took the point of view that in some instances it was reasonable for costs to exceed the limit and for the patient to bear the burden of the excess. In other cases it was hoped that patients and the community together would act so as to create pressure for the institution to lower its costs below the limit. The words of the committee report on this point are:

Where the high costs do in fact flow from the provision of services in excess of or more expensive than generally considered necessary to the efficient provision of appropriate patient care, patients may nevertheless desire such services. It is not the committee's view that if patients desire unusually expensive service they should be denied the service. However, it is unreasonable for medicare or medicaid (which are financed by almost all people in the country rather than the patient or community that wants the expensive services) to pay for it.

Similarly, when the high costs flow from inefficiency in the delivery of needed health care services the institution should not be shielded from the economic consequences of its inefficiency. Health care institutions, like other entities in our economy, should be encouraged to perform efficiently, and when they fail to do so should expect to suffer the financial consequences. Unfortunately, a reimbursement mechanism that responds to whatever costs a particular institution incurs presents obstacles to the achievement of these objectives. It is believed that they can only be accomplished by reimbursement mechanisms that limit reimbursement to the costs that would be incurred by a reasonably prudent and costconscious management. ${ }^{32}$

\footnotetext{
11 Id. at 84 .

${ }^{83}$ Id. at 83 .
} 
The pressures on the patient and the institution that the committee contemplated were intended to counterbalance some of the present pressures for ever higher costs. The hospital administrator tends to be rewarded more for making his hospital a prestige institution than for making it cheap. Hospital trustees are generally more enthusiastic about a hospital that is famous for its scientific accomplishments than one famous for its economy. Doctors want their hospital to be staffed and equipped to meet all their needs. The patient whose costs are covered through a third party is more concerned about how good the services he receives are than about the impact his own use of services has on the insurance premium. The question for the future is how effectively the pressures added by the limitations that are imposed on costs covered will counteract the many pressures that are exerted to increase costs.

\section{Limits on Prevailing Charges}

Under the original law it was intended that physicians be reimbursed at the level established by the market. The report of the Committee on Ways and Means in Ig65 said,

Where payment by the program is on the basis of charges ..., the carriers would take action to assure that the charge on which the reimbursement is based is reasonable and is not higher than the charge used for reimbursement on behalf of the carriers' own policyholders or subscribers for comparable services and under comparable circumstances. . . . In determining reasonable charges, the carriers would consider the customary charges for similar services generally made by the physician or other person or organization furnishing the covered services, and also the prevailing charges in the locality for similar services. ${ }^{33}$

The thought behind the original law's provisions on reimbursement of physicians was that if Medicare paid the same amount that most non-Medicare patients paid for a service, the program would be protected against overpayment by the marketplace action of other purchasers.

Now the adequacy of protection offered by the medical marketplace seems no longer accepted. In the new spirit the Committee on Ways and Means in adopting further limits on fees that will be reimbursable said,

Your committee believes that it is necessary to move in the direction of an approach to reasonable charge reimbursement that ties recognition of fee increases to appropriate economic indexes so that the program will not merely recognize whatever increases in charges are established in a locality but would limit recognition of charge increases to rates that economic data indicate would be fair to all concerned. ${ }^{34}$

The committee proposed to apply an outer limit to the aggregate of prevailing fees that would be reimbursable. The legislation does not seek to set prices for each individual service but instead establishes a ceiling on the sum of all prevailing fees.

\footnotetext{
${ }^{88}$ H.R. REP. No. 89-213, suspra note 4, at 38 .

${ }^{84}$ H.R. REP. No. 92-23I, silpra note 27 , at 86 .
} 
Individual prices would be set by the market unless the aggregate would then exceed the ceiling to be allowed. If the sum of prices prevailing in the market exceeds the ceiling, the maximum reimbursable level for each service would be determined by adjusting its prevailing market price downward.

\section{Physicians' Services in the Teaching Setting}

The original Medicare law provided that physicians' services (other than those of an intern or resident) would be paid for on the basis of the reasonable charge for the service. ${ }^{35}$ No discussion is included in either the law itself or the committee reports with regard to any special rules to be applied in the case of physician services not normally paid for on the basis of charges to a patient. A case in point occurs where a patient is admitted to a so-called teaching hospital; much of his services are provided by interns and residents supervised by a fully qualified physician, and before Medicare (and often now for non-Medicare patients) he would have paid little or no charge for his physicians' services. As Medicare developed, bills increasingly seemed to be prepared for the physicians' services received by patients whose care was largely entrusted to residents that were similar in amount to bills that would have been submitted where the supervising physician had rendered the full service to the patient. The supervising physicians' services in the cases varied over a broad range of actual involvement and were sometimes limited to the mere fact of their legal responsibility for the quality of care. It has been difficult to apply a uniform and fair policy for paying for the widely varying services of supervising physicians in varying settings. It has been most difficult to learn which services were in fact provided by whom in an individual case to arrive at a fee-for-service. Social Security Administration and General Accounting Office studies indicated that some hospitals had billed and been paid excessively for the services that were provided.

In attempting to provide a legislative solution to the problem, the Committee on Ways and Means recommended a change from fee-for-service to cost reimbursement where charges are not normally made outside the Medicare setting. ${ }^{36}$ As mentioned above, H.R. I as reported by the committee in I97I was substantially more restrictive in this respect than the I970 House-passed version of H.R. I7550, but it also allowed for a sweetener-payment for the salary cost equivalent of teaching services donated by supervisory physicians. The provisions in H.R. I regarding teaching physicians followed the approach taken by the Senate in 1970 .

\section{E. Health Maintenance Organizations}

For a number of years many of the persons who have urged a major reorganization of the medical care system have suggested as a model for a restructured approach the group practice prepayment plans, of which the largest are the Kaiser Permanente plans and the Health Insurance Plan of Greater New York. The support for group

\footnotetext{
${ }^{35}$ Health Insurance for the Aged, 42 U.S.C. § $1395 f(b)$ ( 1965$)$.

${ }^{80}$ H.R. REP. No. 92-23I, supra note 27 , at 94 .
} 
practice has derived in part from what is believed to be more effective use by these plans of the health funds provided. Organized labor has long supported such plans, but organized medicine has had considerable reservations about the closed-panel approach to the practice of medicine, under which patients have their care paid for only if they use a relatively small number of doctors participating in the plan.

In its report on the original Medicare law, the Committee on Ways and Means had this to say about its action on group practice prepayment plans:

$[N]$ o special recognition is being given to the lower rate of hospital utilization which might be experienced by aged persons under comprehensive health care plans. However, it is not the intention of your committee by this action to adversely affect those organizations which provide and operate comprehensive health care services. On the other hand, it is the hope of your committee that the development of comprehensive health care plans be encouraged. ${ }^{37}$

As health costs have risen, support for group practice prepayment plans has widened and has attracted an increasing number of adherents from the business sector. The support of the administration for a health maintenance organization option seems largely tied to a conviction that such an option would aid in bringing some of the advantages of commercial enterprise to the health field. The Committee on Ways and Means, in accepting the administration recommendation, seemed to express such a view when it said:

Because the [health maintenance] organization receives a fixed annual payment from enrollees regardless of the volume of services rendered, there is a financial incentive to control costs and to provide only the least expensive service that is appropriate and adequate for the enrollee's needs. ${ }^{38}$

\section{Conclusion}

At this point in time the Social Security Amendments of I97I are still a matter of conjecture. Despite industry reservations about some of the cost control provisions, no minority views were expressed about them when the bill was reported out of committee either in 1970 or $x 97 x$. In adopting these changes the committee displayed both a willingness to provide controls over industry opposition and also considerable sophistication and therefore reservations about the effects to be anticipated. It summarized its views on the provisions by saying,

Your committee ... concluded that there is no simple or single solution to the problems now existing in the health care field which adversely affect these programs. But your committee does believe that there are modifications which can and should be made in these programs-changes which, while perhaps not very significant taken singly, as a whole show great promise for making significant advances in accomplishing the goal of making these programs more economical and more capable of carrying out their original purposes. ${ }^{39}$

\footnotetext{
${ }^{87}$ H.R. REP. No. 89-213, supra note 4, at 22.

${ }^{38}$ H.R. REP. No. 92-23I, supra note 27 , at 89.

${ }^{80} I d$. at 6.
} 
The 1970 bill passed the House by a vote of 343 to 32 , and the only controversy about the bill that was raised in the course of the 1970 House debate was related to its failure to include provisions for automatic adjustments in cash benefits as price levels change. These Medicare provisions seem unlikely to start more debate this year. There seems, then, to be virtual unanimity on the control aspects of the Medicare provisions, and although little was added in the House bill to the controls originally proposed by the administration, this does not necessarily indicate that the administration's plan went as far as the committee or the House was willing to go. It may be, rather, that in a technical area such as medical cost controls, even the unusually competent Committee on Ways and Means depends on the executive to develop the basic plan of action.

Assuming passage by the House, the question remains as to how the Senate Finance Committee and the Senate as a whole will react. The action of the Senate in 1970 provides some ideas of changes that may be made in H.R. I as it passes through the legislative process. The proposal for peer review sponsored by Senator Bennett seems likely again to receive strong support. Other additions to the Medicare provisions of H.R. I7550 made by the Senate Finance Committee were a provision establishing the position of Inspector General to check on Medicare and Medicaid administration and a provision providing for prospective reimbursement by Medicare of extended care facilities where such reimbursement was related to state rates of payment under Medicaid and where in turn the state rate had been found to be reasonably related to the cost of services provided. ${ }^{40}$

Finally, the Senate Finance Committee had added to H.R. I7550 a very major provision. This was a proposal to establish under the Social Security Act a new Catastrophic Health Insurance program for persons under sixty-five, financed by payroll contributions from employees, employers, and the self-employed. The purpose of the proposal was to provide federal insurance, complementary to private health insurance, that would mitigate the financial effects on families and individuals of unusually prolonged or expensive illnesses. ${ }^{41}$ The question of catastrophic health insurance protection may arise, since Senator Long has reintroduced the proposal in the Senate. ${ }^{42}$ Whether it will be considered in connection with H.R. I is open to question, though, since the Committee on Ways and Means is scheduled to take up national health insurance and action on catastrophic health insurance may await action by the Committee on Ways and Means on this very broad issue. Thus, the most important possible action on federal health insurance this year is still a matter of total uncertainty. Suspense seems to be one of the characteristics of the American political system.

\footnotetext{
${ }^{80}$ H.R. $x 7550$, 91st Cong., 2d Sess. $\$ \$ 24 \mathrm{I}, 265$ (1970).

¿1 S. REP. No. 9I-I 43I, 9Ist Cong., $2 d$ Sess. I85 (I970).

${ }^{42}$ S. 1376, 92d Cong., Ist Sess. (197I).
} 